DOI: https://doi.org/10.32839/2304-5809/2020-7-83-37

UDC 811.111.161.2'25

Miroshnychenko Olena, Demydenko Olga

National Technical University of Ukraine

"Igor Sikorsky Kyiv Polytechnic Institute"

\title{
GENRE-STYLISTIC AND LEXICO-SEMANTIC FEATURES F ENGLISH PROFESSIONAL TEXTS TRANSLATION
}

Summary. The proposed article is devoted to the study of genre-stylistic and lexical-semantic features of the exact sciences texts translation from the English language into Ukrainian. For this study a lot of scientific works as well as original English scientific texts and their Ukrainian translations were studied. The main criterion that distinguishes one genre of scientific and technical literature from another is the functional purpose of the text. Knowledge of the peculiarities of multidisciplinary texts determines the correct selection of the appropriate language tools during translation and contributes to the creation of adequate translation. Terms are the basis of professional texts both in quantitative and semantic representations, so the data on the terminological richness of professional texts is important for the study of translation. Special attention is paid to the translation transformations for terms of the exact sciences.

Keywords: professional text, term, exact sciences, equivalent, translation transformations.

Мірошниченко О.І., Демиденко О.П.

Національний технічний університет України

«Київський політехнічний інститут імені Ігоря Сікорського»

\section{ЖАНРОВО-СТИЛІСТИЧНІ ТА ЛЕКСИКО-СЕМАНТИЧНІ ОСОБЛИВОСТІ ПЕРЕКЛАДУ АНГЛОМОВНИХ ФАХОВИХ ТЕКСТІВ}

Анотація. Ця стаття присвячена вивченню жанрово-стилістичних та лексико-семантичних особливостей перекладу фахових текстів з галузей точних наук з англійської мови на українську. Для цього дослідження було опрацьовано багато наукових праць, а також оригінальні англійські тексти математичної, фрізичної, комп'ютерної тематики та їх українські переклади. Основним критерієм, що відрізняє один жанр науково-технічної літератури від іншого, е функціональне призначення тексту. Фахові тексти можуть бути офіційно-діловими, науковими, технічними, публіцистичними та розмовними. Знання особливостей мультидисциплінарних текстів визначає правильність підбору відповідних мовних засобів під час перекладу та сприяе створенню адекватного перекладу. У статті наводяться основні фрункції та тональності фахових текстів, а також типи інформації, які в них переважають. Терміни $є$ основою фахових текстів як у кількісному, так і в смисловому відношенні, тому дані про термінологічну насиченість фрахових текстів мають важливе значення для вивчення перекладу. Особлива увага приділяється перекладацьким трансформаціям термінів точних наук. У статті розглянуто лексичні (транскрипція, транслітерація, змішане транскодування, адаптивне транскодування, калькування), лексико-семантичні (конкретизація, генералізація, модуляція), лексико-граматичні (експлікація, дескриптивне перифразування, функціональна заміна) та граматичні (додавання, вилучення, граматична заміна) перекладацькі трансформації. Для кращого розуміння наводиться велика кількість яскравих прикладів англійською мовою та їх переклад на українську. Більш того, було доведено, що незважаючи на поширену ідею певної «сухості», науковості та точності викладу матеріалу у фахових текстів, їм властива образність, тобто, передавання певних понять через художні образи, оригінальність та метафоричність. Ця стаття заохочуе подальше вивчення особливостей перекладу фрахових текстів. Результати дослідження можуть стати у нагоді будь-якому лінгвісту та перекладачеві для адекватного перекладу з англійської мови на українську.

Ключові слова: фаховий текст, термін, точні науки, еквівалент, перекладацькі трансформації.

$\mathrm{T}$ he problem under discussion. The research is due to the rapid development of relations on the international stage in various professional fields, which requires fundamental studies of particular aspects of the professional texts translation. Although this problem has been partially investigated in theoretical terms, it is difficult to agree that this issue has now been reviewed exhaustively, as the translator faces new difficulties in translating professional texts in various fields.

Analysis of recent research and publications. The problems of professional translation have attracted the attention of many scholars, as evidenced by the significant amount of scientific papers and publications on this topic. First of all, we should mention such well-known Ukrainian and foreign translators and linguists as R. Arntz, K. Bauman, G. Budin, G. Vermeer, W. Wills, V. Karaban, T. Kiyak, D. Lotte, K. Nord, R. Stoltse. The problem of studying professional vocabulary was considered in the works of scientists such as T.L. Kandelaki, V.P. Danylenko, G.O. Vinokur, K. Averbukh, A.A. Reformatsky, O.S. Akhmanova, N. Kotelova, S.V. Grinev and others.

The aim of the article is to identify the main features of the professional English texts translation related to the exact sciences. The attainment of the agreed aim requires solving specific tasks:

- to analyze theoretical sources on this issue;

- to identify the main ways of translating English terms of exact sciences into Ukrainian;

- to illustrate the features of professional texts translation on the basis of salient examples. 


\section{Results and discussion. \\ 1. The Analysis of Professionally-Oriented} Texts.

Professionally-oriented or simply professional and special text is a text intended for a circle of specialists in a certain field of knowledge, which contains professionally relevant information that promotes the exchange of professional knowledge.

The leading functions of such texts are denotative (reporting of facts); commanding or volitional (prescription of actions); metalinguistic (description of the linguistic system when it comes to the language). The tonality of such texts is neutral or altered (business).

Types of information contained in such texts are:

1) cognitive (objective information about the external world characterized by three parameters such as objectivity (reality of the text, lack of the emotional connotation, use of terms), abstractness (logic of the text), density or compressibility (the use of abbreviations, numbers, formulas, graphs, figures, etc.);

2) prompt or appealing (incitement, call for certain actions, as, for example, in instructions, proclamations);

3) emotional (transfer of emotions and feelings but much less often than in other types of texts) [7, p. 44-87].

Characteristic features of the special texts are their informativeness, consistency (strict sequence, clear connection between the main idea and details), accuracy, clarity and comprehensibility. Texts belonging to this style may possess the indicated features to a greater or lesser extent. All such texts reveal the predominant use of language tools that contribute to meeting the needs of the specific sphere of communication [2, p. 55-89].

2. Peculiarities of the Translation of Professional Texts.

English special texts are incredibly difficult both for perception and translation. The texts are full of all kinds of linguistic means, which greatly complicate the entire process of translating the text. Therefore, those means need to be correctly interpreted.

Translation of special texts is a complex, rather painstaking activity, which requires the presence of certain skills and knowledge from the translator, because the result of the work of specialists who are interested in studying this scientific work will directly depend on the quality of the translation. Special translation is a translation of special texts, i.e., texts related to a particular scientific field that has its own terminology, or to several fields. Thus, almost any non-fiction text can be called a special text, the content of which generally refers to a specific topic, which is quite typical for communication [5, p. 158-177].

Special translation breaks down into four types corresponding to functional styles, i.e. translation: official texts (diplomatic, legal, military, commercial, laws, orders, decrees, characteristics, protocols, receipts, certificates, etc.); scientific and technical texts (relating to various subject areas of science and technology); journalistic texts (serving to influence people through the media: information is intended for wide sections of society, the impact is directed not only to the mind, but also to the feel- ings of the recipient); texts of everyday communication (colloquial and vernacular vocabulary are used: dialogues, personal letters, notes, telephone conversations, etc.).

It is believed that all professional texts are short, concise, monotonous, that the terminology of such texts is accurate and standardized, and the style is dry and devoid of imagery. This is true, however, within certain limits. In practice, translator is confronted with scientific and technical texts that simply amaze with their sophistication and vividness of the presentation. The translation of these texts is close in its characteristics to the literary ones. The process of translating such texts takes longer than that of standard texts, but it is more interesting from the point of view of the translation practice. For example, "This site uses cookies, that is, small text files that are stored on your computer to make the site easier to use." ("На uьомy сайті використовуються реп'яшки - маленькі текстові ббайли, котрі зберігаються на вашому компютері з метою полегшення використання caümy"). Such vivid texts are not often found in practice. This is due, firstly, to the structural differences between the two languages, and secondly, to the wide genre diversity of the scientific and technical style [4, p. 326-359].

A prerequisite for adequate translation of any professional text is its full understanding by the translators, so they must understand the field of science in which they work. When translating professional texts, the translator must take into account the relations between the term and the context, so that the meaning of the lexical unit is revealed. Thus, the main task of the translator of multidisciplinary texts is to convey as accurately as possible the meaning of terms that overload the professional texts.

Also, real difficulties for the translator are created by so-called pseudo-internationalisms or «false friends of translators", i.e. words that have the same or similar form in two languages, but their meanings in these languages are different. For example, "silicone» is "кремній», not «силікон»; "accurate» is "точний», not «акуратний»; «data» is «дані», not «дата» [3, p. 111-118].

\section{The Ways of Translation terms in the pro-} fessional texts.

The richness in terms is one of the defining characteristics of a scientific and technical text. Each term must be based on a definition, so that the term is an accurate and at the same time concise description of an object or phenomenon. The term can be formed on the basis of one language or borrowed from another one.

The main way of translating professional terms is the selection of the lexical equivalent in the language of translation, which is registered in the dictionary and exactly coincides with the meaning of the original term. According to V.I. Karaban, the translation of multi-equivalent terms requires the translator to be able to find an adequate equivalent in a certain context. If there are no dictionary equivalents for professional terms, translators use various methods of translation transformations [6, p. 66-108].

In our article, translation transformations were divided into lexical, lexical-semantic, lexical-grammatical and grammatical. All these types of transfor- 
mations can be used for translating terminology of exact and natural sciences from English into Ukrainian.

Lexical transformations:

- transcription: "New processor three times more capable than this current system» («Новий процесор в три рази потужніший, ніж нинішня систела»);

- transliteration: "After the war the monitor was used for testing of different weapon systems" («Після війни монітор використовувався для випробування різних систел озброєння»);

- mixed transcoding: "Portable fission device, five-kiloton yield» ("Портативний девайс розщепленняядра, потужністю п'ять кілотонн»);

- adaptive transcoding: "In 1897, a telephone cable to the mainland was laid» («Y 1897 poui прокладено телефбонний кабель до материка»);

- calque/loan translation: "Press the button with the pencil image or hot key F4 on the keyboard to open the record editor» («Цоб відкрити вікно редагування запису, треба натиснути на кнопку із зображенням олівия, або гарячу клавішу F4 на клавіатурі»).

Lexical and semantic transformations:

- concretization: "Space motion have been designed to investigate the physics of the phenomena» («Ведеться підготовка кослічних польотів для вивчення фбізики явищ»);

- generalization: "Depression can really affect you in the long run» ("психічний розлад може тривати довгий час»);

- modulation: "Excess heat can cause computer freeze» ("Через перегрівання операційна систела ложе не реагувати на дії користувача"). Операційна система перестає виконувати фрункції як наслідок зависання комп'ютера.

Lexical and grammatical transformations:

- explication: «Native mode: it is installed directly on the system hardware» (Межим роботи у власній системі команд встановлюється безпосередньо на систелне апаратне забезпечення»);

- descriptive periphrasis: "Above we have discussed two graphical frontends to burning" ("Buue ми розповіли про дві графбічні програми для запису компакт-дисків»);
- functional equivalence: "Today there is simply no battery technology capable of meeting the uncommonly high power, long service lifetime and super-low cost» ("На сьогоднішній день не існує технологї, яка дала б нал акулулятор, здатний задовольнити високил вилогал енергосистели, такил як велика потужність, довгий термін служби $і$ дуже низька собівартість»).

Grammatical transformations:

- addition: "Video and jukebox don't work» («Відео $m a$ дисковод 3 автоматичною заміною дисків не працюють»);

- compression: "He was coptered out with a serious injury» ("Його евакуювали із серйозною травлою») («copter» - летіти на вертольоті, перевозити вертольотом). У цьому випадку оригінал містить більше інформації, оскільки вказано чим саме була евакуйована людина, в перекладі цю інформацію вилучили;

- grammatical replacement: зміна типів речення (англійське просте речення перетворилося на українське складнопідрядне речення мети: «The touchpad is needed to move the cursor across the display screen" ("Потрібна сенсорна панель, шоб керувати курсором по екрану») [1; 4, р. 326-359; 5, p. 158-177; 8; 9].

Conclusions and scope for further research. During the analysis of professional texts of exact sciences and their Ukrainian translations it was revealed that professional multidisciplinary texts have certain features that constitute major challenges for a translator. First of all, we are talking about terms, the translation of which requires a precise understanding of the specifics of the field in which the translator works. The main way of translating professional terms is the selection of a regular dictionary equivalent, which exists in the language of translation and accurately conveys the content of a specific language unit to denote certain objects and phenomena. In the process of comparative analysis of the original text and the translated text, it was determined that professional terms can also be skillfully translated with the help of certain translation transformations.

\section{References:}

1. Brain Games. URL: https://www.nationalgeographic.com.au/tv/brain-games/

2. Brandes, M.P. (2004). Stilistika teksta. Teoreticheskij kurs (3rd ed.) [Text's stylistics. The theoretical course]. Moscow: Progress-Tradiciya; INFRA. (in Russian)

3. Dyakov, A.S., Kiyak, T.R., \& Kudelko, Z.B. (2000). Osnovi terminotvorennya: Semantichnij ta sociolingvistichnij aspekti [The basics of terminology creation: Semantic and Sociolinguistics aspects]. Kyiv: KMAcademia. (in Ukrainian)

4. Karaban, V.I. (2004). Pereklad anglijskoi naukovoi i tekhnichnoi literaturi. Gramatichni trudnoshchi, leksichni, terminologichni ta zhanrovo-stilistichni problemi [The translation of English scientific and technical literature. Grammatical difficulties, lexical, terminological and genre-stylistic problems]. Vinnicya: Nova kniga. (in Ukrainian)

5. Korunec, I.V. (2008). Vstup do perekladoznavstva [Introduction to the translation studies]. Pidruchnik. Vinnicya: Nova kniga. (in Ukrainian)

6. Kovalenko, A.Y. (2001). Zagalnij kurs naukovo-tekhnichnogo perekladu: Navchalnij posibnik [The general course of the scientific and technical translation]. Vinnicya: Nova kniga. (in Ukrainian)

7. Mishchenko, A.L. (2013). Lingvistika fahovih mov ta suchasna model naukovo-tekhnichnogo perekladu: monografiya [Linguistics of the special text and modern model of the scientific and technical translation]. Vinnicya: Nova kniga. (in Ukrainian)

8. Silicon Cowboys. URL: https://www.netflix.com/ua/title/80104318

9. The Secret Rules of Modern Living: Algorithms. URL: https://www.imdb.com/title/tt5818010/ 